\title{
Innovative Learning through Fun Thinkers Media Based on Fill the Blank Question
}

\section{Ni Putu Feby Mulia Buana Rosnata1*, I Gusti Ayu Tri Agustiana ${ }^{2}$, I Ketut Dibia ${ }^{3}$}

\author{
1,2,3 Departement of Elementary Education, Ganesha University of Education, Singaraja, Indonesia
}

\section{A R T I C L E I N F O}

Article history:

Received March 20, 2021

Revised March 21, 2021

Accepted June 22, 2021

Available online August 25, 2021

Kata Kunci:

Fun Thinkers, Fill The Blank

Keywords:

Fun Thinkers, Fill The Blank

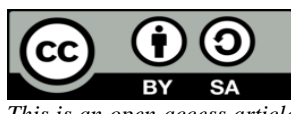

This is an open access article under the CC BY-SA license.

Copyright (C) 2021 by Author. Published by Universitas Pendidikan Ganesha.

\section{A B S T R A C T}

Lack of student understanding of the material provided online by the teacher, students feel bored with monotonous learning using mobile phones, teachers provide materials and assignments through student books, the media used is still simple and less attractive. This study aims to develop media fun thinkers based on fill the blank questions for grade 1 elementary school students on theme 3 of my activities. Media development in this study is guided by the ADDIE model procedure which consists of several stages, namely analysis (Analyze), planning (Design), development (Development), implementation (Implementation), and evaluation (Evaluation). The trial subjects of this study consisted of 2 subject matter experts, 2 media experts, 2 practitioner responses, and 10 student responses (small groups). The data collected in this study, namely qualitative data and quantitative data. Data was collected using a questionnaire method with the distribution of rating scale instruments. The results showed that the average validity and reliability scores from the point of view of material experts were 4.3 with very valid qualifications and $93 \%$ with reliable qualifications, in terms of media experts it was 4.4 with very valid qualifications and $92 \%$ with reliable qualifications, from In terms of practitioner responses, it is 4.6 with very valid qualifications and $96 \%$ with reliable qualifications, and in terms of student responses it is 4.8 with very valid qualifications and $97 \%$ with reliable qualifications. This shows that the media fun thinkers based on fill the blank questions for elementary school students in grade 1 on theme 3 of my activities is declared suitable for use in learning. The implications of this research are expected to help students during online learning.

\section{INTRODUCTION}

Corona virus has infected millions of people in more than 200 countries around the world and caused death. One of them is Indonesia (Ertem et al., 2021; Handayani et al., 2020; Nurkholis, 2020; Talevi et al., 2020). The government anticipates the spread of Covid-19 by issuing policies such as carrying out activities at home, social restrictions, physical distancing, wearing personal protective equipment such as masks, maintaining personal hygiene, working and studying from home (Franchi, 2020; Gollwitzer et al., 2021; Mansyur, 2020; Susilo et al., 2020). During the Covid-19 pandemic, learning in schools was carried out online. Online learning is a learning system that is held online using internet (Harahap et al., 2021; Mauludy, 2020; Putria et al., 2020). During online learning, teachers have to ensure that teaching and 
learning activities run appropriately, also ensure that students understand the subject matter provided even though learning is carried out online. Online learning is done by using supporting tools such as computers, laptops or mobile phones that connected to the internet (Putria et al., 2020). Teachers and students can do online learning by using Whatsapp, Zoom, Google Classroom or other applications (Siahaan, 2020; Syafari \& Montessori, 2020; Yuliani \& Saputri, 2021). Doing online learning means new innovations in learning activities need to be done by teachers to convey the material being taught to students (Anugrahana, 2020; Kristiawan et al., 2021).

The problem that occurs in the field is that online learning has not been implemented properly (Asmuni, 2020; Ota et al., 2021). Students have difficulty in online learning (Dewi, 2020; Harahap et al., 2021). In the online learning process, the teacher only uses the assignment method so that students have difficulty to understand the learning material (Herlina \& Suherman, 2020; Rigianti, 2020; Siahaan, 2020). Monotonous learning makes students easily bored and causes lack of motivation (Lilawati, 2020; Mansyur, 2020; Pertiwi et al., 2019). These are due to changes in learning patterns from face-to-facelearning to online learning so that teachers and students have not ready to perform effective learning. The same problem is also found in SD Gugus IX Buleleng when carrying out online learning activities, some of which are some students and parents who do not have mobile phone to support learning activities, bad internet connection, student lack of understanding on the material provided online by the teachers, students feel bored with monotonous learning via mobile phones, excessive use of textbook for subject explanation and assignment, the media used is too simple and less attractive. If these problems are ignored, they will give negative impacts on the student learning process. For this reason, learning media is needed to support student learning activities. If learning media is not used, students will find it difficult to understand the material to be taught. Learning media is also very useful to ease positive learning styles which will have good impacts on students' interest in learning.

The solution that can be offered to overcome these problems is by developing learning media. In the learning process, media is very important in order to support learning process (Maqfiroh et al., 2020; Putri, 2017). One of the innovative media which attracts students' interest and intelligence is fun thinkers media. Fun thinkers media can attract students' interest and help students understand the subject, so as to improve student learning outcomes (Andriyani \& Suniasih, 2021; Rezeki \& Atikah, 2020; Soucy et al., 2016; Taqiya et al., 2019). This will stimulate and increase student motivation in learning. Learning media is a graphic tool for receiving, processing, and rearranging visual or verbal information (Afifah, 2019; Tafonao, 2018; Zulfana et al., 2020). This media is a means of communication and interaction between teachers and students in learning. In addition, the media can also increase student enthusiasm in learning so that it has an impact on increasing student learning outcomes (Heo \& Toomey, 2020; Khamparia \& Pandey, 2017). One of the innovative media that can help students learn is fun thinkers media based on fill-the-blank-question. This media will help students learn with fun through interesting pictures (Rezeki \& Atikah, 2020). This media also has the potential to help students in problem solving through the exercise given.

The findings of previous research regarding fun thinkers media also state that fun thinkers media can increase students' enthusiasm for learning (Bakhri, 2019; Megawati, 2021; Rezeki \& Atikah, 2020). Other research findings also state that concrete media can increase students' enthusiasm and learning outcomes (Arianti et al., 2019; Hadiyati \& Wijayanti, 2017). Fill-the-blank-question style used are in accordance with the characteristics of elementary school students, making it easier for students to learn the material, besides that it can stimulate students to think critically. The weakness of previous research is that they do not give exercise to the media so that it is less challenging for students. In addition, there is no study on learning media for fun thinkers based on fill-the-blank-question that can help students understand learning material in theme 3 my activities. The advantage of the media that will be developed is that the addition of certain images that are in accordance with the subject matter to ease students to understand the subject matter. In addition, there are various fill-the-blank-question on fun thinkers media that can improve students' thinking skills in learning. The purpose of this research is to develop media for fun thinkers based on fill-the-blank-question that can help students understand thematic learning in grade I, theme 3 My Activity. It is hoped that this media can help students in learning so that it can improve student learning outcomes during online learning.

\section{METHOD}

This type of research is learning media development research (research \& development) in the form of fun thinkers media based on fill-the-blank-question for elementary school students in grade 1 on theme 3 my activities. This study uses the ADDIE research model (Analyze, Design, Development, Implementation, Evaluation). The selection of the ADDIE model is based on the consideration that the 
model is easy to understand, and has a systematic stage and is based on the theoretical foundation of learning design. The research development design is presented in Figure 1.

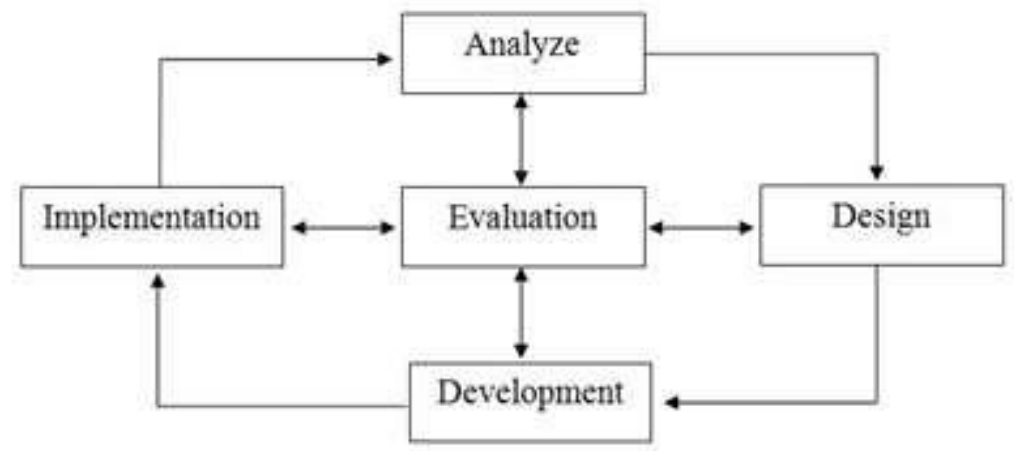

Figure 1. Research design with ADDIE Model

The subjects in this study are 2 material experts, 2 media experts, 2 practitioners and 10 students. The techniques used in collecting data in this study are observation, and questionnaires. The data collection instrument used in this study is a rating scale instrument. The draft of data collection instruments to determine the validity of the developed learning media is presented in Table $1,2,3$, and 4 .

Table 1. Grid of Expert Test Instruments for Question Materials

\begin{tabular}{|c|c|c|c|c|}
\hline No. & Aspect & Indicator & $\begin{array}{c}\text { Item } \\
\text { Number }\end{array}$ & $\begin{array}{l}\text { Number of } \\
\text { Items }\end{array}$ \\
\hline 1. & $\begin{array}{l}\text { Language } \\
\text { use }\end{array}$ & Quality of language use & $\begin{array}{c}1,2,3,4,5 \\
6,7\end{array}$ & 7 \\
\hline \multirow[t]{6}{*}{2.} & $\begin{array}{l}\text { Fill in the } \\
\text { question }\end{array}$ & $\begin{array}{l}\text { Clarity and completeness of identity Curriculum } \\
13 \text { media fun thinkers. }\end{array}$ & 8 & 1 \\
\hline & & $\begin{array}{l}\text { The relevance of the question material to basic } \\
\text { competencies. }\end{array}$ & 9 & 1 \\
\hline & & $\begin{array}{l}\text { The relevance of the question material to the } \\
\text { indicators. }\end{array}$ & 10 & 1 \\
\hline & & $\begin{array}{l}\text { The relevance of the question material to the } \\
\text { level of student development. }\end{array}$ & 11 & 1 \\
\hline & & $\begin{array}{l}\text { The relevance of the question material to the } \\
\text { charge of fill the blank. }\end{array}$ & $12,13,14$ & 3 \\
\hline & & Number of items & & 14 \\
\hline
\end{tabular}

Tabel 2. Media Expert Test Instrument Grid

\begin{tabular}{|c|c|c|c|c|}
\hline No. & Aspect & Indicator & Item Number & $\begin{array}{c}\text { Number of } \\
\text { Items }\end{array}$ \\
\hline \multirow[t]{5}{*}{1} & Media Design & Media cover design. & $1,2,3$ & 3 \\
\hline & & Image quality displayed. & 4,5 & 2 \\
\hline & & The clarity of the displayed text. & $6,7,8$ & 3 \\
\hline & & Media display. & 9,10 & 2 \\
\hline & & Layout. & $11,12,13,14$ & 4 \\
\hline 2 & Language use & Quality of language use. & $15,16,17$ & 3 \\
\hline \multirow[t]{3}{*}{3} & Ease of use & Ease of use of media. & 18,19 & 2 \\
\hline & & Clarity of media usage. & 20 & 1 \\
\hline & & Number of items & & 20 \\
\hline
\end{tabular}

Tabel 3. Expert Practitioner Test Instrument Grid

\begin{tabular}{cclcc}
\hline No. & \multicolumn{1}{c}{ Aspect } & \multicolumn{1}{c}{ Indicator } & Item Number & Number of Items \\
\hline 1 & Media serving & Media technical quality. & $1,2,3,4,5$ & 5 \\
2 & Media quality & $\begin{array}{l}\text { Quality of content in the } \\
\text { media. }\end{array}$ & $6,7,8,9,10$ & 5 \\
& & & \\
\cline { 2 - 4 }
\end{tabular}




\begin{tabular}{|c|c|c|c|c|}
\hline No. & Aspect & Indicator & Item Number & Number of Items \\
\hline & & $\begin{array}{l}\text { Quality of questions based on } \\
\text { fill the blank questions. }\end{array}$ & $11,12,13,14,15$ & 5 \\
\hline & & Instructional quality. & $16,17,18,19,20$ & 5 \\
\hline & & Number of items & & 20 \\
\hline
\end{tabular}

Table 4. Students Responses Instrument Grid

\begin{tabular}{cllcc}
\hline No. & Aspect & Indicator & Item Number & Number of Items \\
\hline 1 & Question material & Retention of material. & $1,2,3,4,5$ & 5 \\
2 & Media use & Ease of using media in learning & $6,7,8,9,10$ & 5 \\
\hline \multicolumn{4}{c}{ Number of items } \\
\hline
\end{tabular}

Content validity is a requirement of feasibility and quality in the instrument. Content validity is used to measure the validity level of the instrument draft of fun thinkers media that has compiled. The content validity test of the instrument is carried out through the assessment of experts (judges) or experts in their fields who have competence in the variables being studied. This validity test is carried out using the Gregory formula. After the instrument is declared valid, the instrument reliability test will be proceed. The validity test is done to determine the consistency of the instrument or in other words, to find the extent to which the measurement results remain consistent when it is used repeatedly. Based on the standard percentage agreement, the four instruments are in very good criteria. Data analysis methods and techniques used in this development research are qualitative descriptive statistical analysis techniques and quantitative descriptive statistics. Qualitative descriptive statistical analysis is used in processing the results of reviews, suggestions, inputs made by experts or judges on the developed learning media. Quantitative descriptive statistical analysis is used to process data in the form of scores obtained from giving assessment sheets for developed fun thinkers media instruments to material experts, learning media, teachers and students. In making decisions regarding media development, a reference scale of 1-5 is used.

\section{RESULT AND DISCUSSION}

Result

The development of fun thinkers media based on fill-the-blank-question in theme 3 my activities has been carried out using the ADDIE development model. Development begins at the analysis, design, development, implementation, and evaluation stages. The first step is analysis. At this stage, an analysis of needs, curriculum, media and an analysis of the student characteristics is done. The results of the needs analysis show that there is a need for learning media that can be used by teachers and students in learning activities during the covid-19 pandemic. The results of the curriculum analysis obtained by analyzing KI, $\mathrm{KD}$, indicators of competency achievement, learning objectives, and learning materials contained in the textbook as a basis for compiling the developed learning media. The fun thinkers media that is developed focused on grade 1 elementary school students with the theme 3 of my activities in accordance with the curriculum 2013. The results of the analysis of student characteristics show that students at the elementary school level are still in the concrete operational stage. Where students still have a concrete level of thinking. The results of the media analysis are intended to be able to show that the criteria for a good media can be seen from the effectiveness, efficiency, communicative and fulfill several aspects of validity.

The second stage is the design stage. The design stage is carried out by designing instruments and making media designs. The instruments designed that is used for media assessment are material expert validation instruments, media expert validation instruments, practitioner response instruments, and student response instruments. The four instruments have been carried out and show the results that the four media assessment instruments have high validity and very good reliability. It means that all of the items of the assessment instrument have met the media validity aspect. Other than compiling the instrument, the design is also made by using the Photoshop CS5 application. The media developed is made from A3 size paper consisting of 50 pages including the cover. The frame has a size of $18 \times 19 \mathrm{~cm}$ and $4 \times 4$ $\mathrm{cm}$ on a block tile box. The material used is glossy paper and acrylic-material frame. The media developed is designed with attractive colors and images according to the student characteristics and suitable for grade 1 elementary school students, theme 3 my activities. 

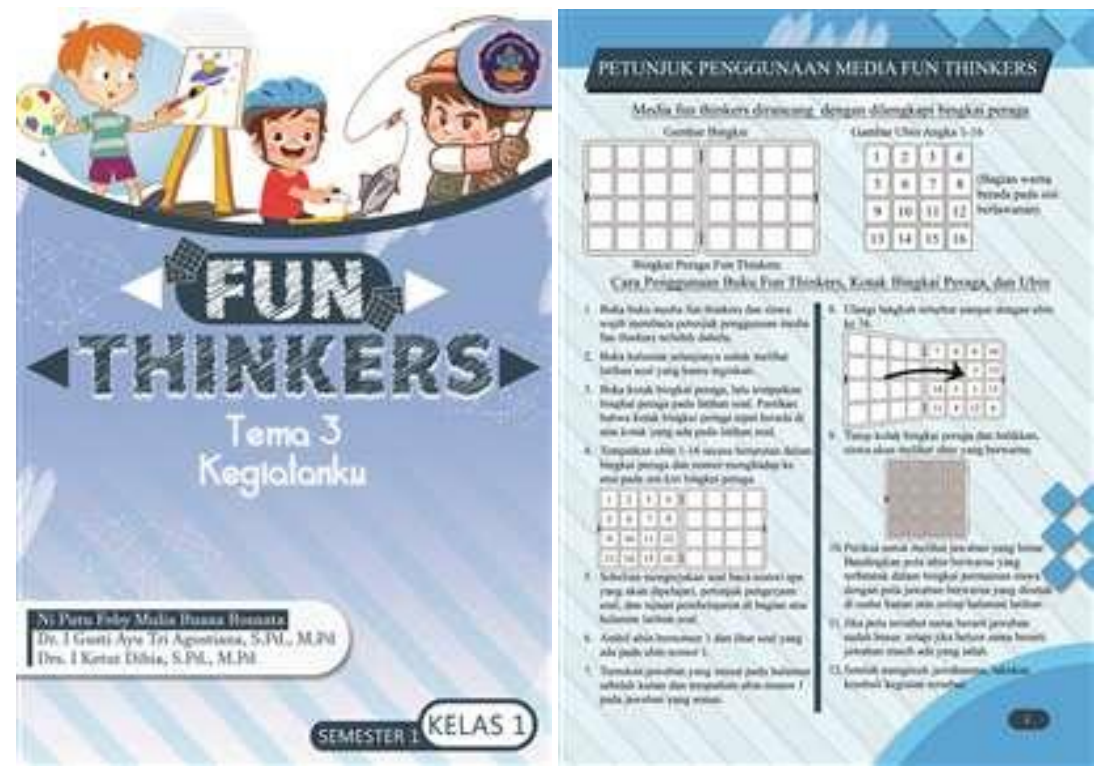

Figure 1. Fun thinkers Media Design Based on Fill the blank questions
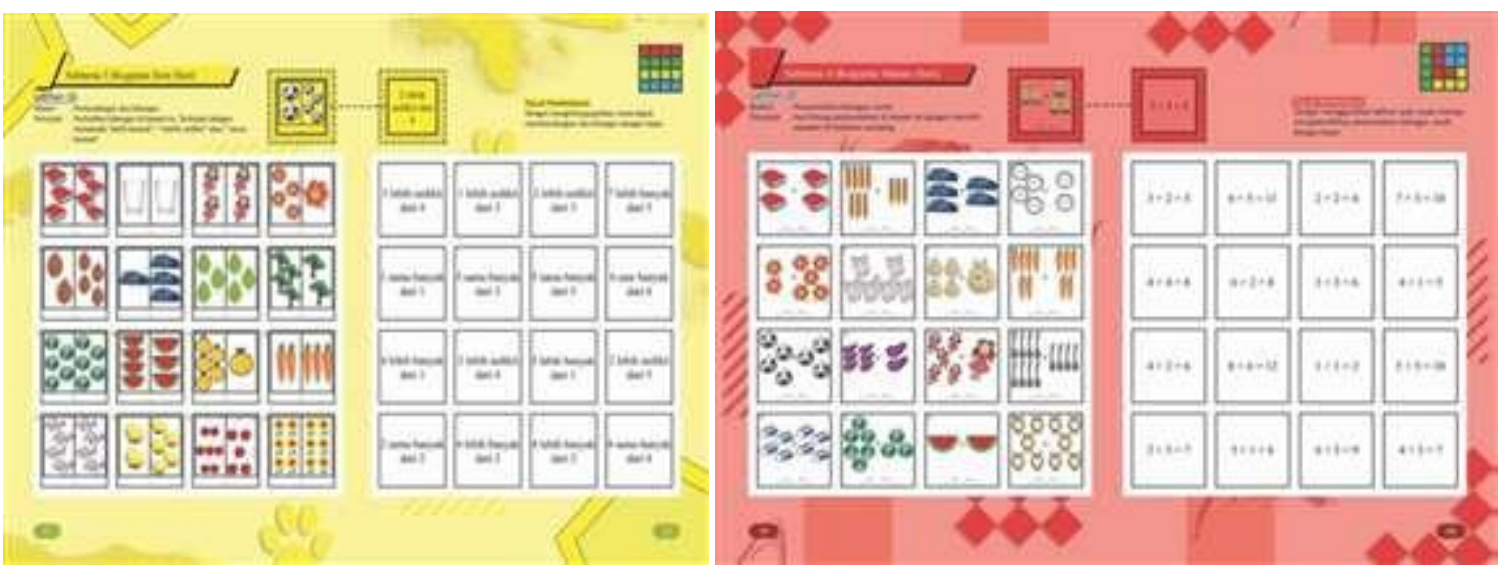

Figure 2. Results of Fun thinkers Media Development Based on Fill the blank questions

The third stage is the development stage, the media development stage is carried out according to the design made and the approval of the supervisor. The media developed consisted of book covers, user guide, Basic Competence (KD) indicators, table of contents, and exercises. After the developing stage, the prototype is tested using the validity-tested questionnaires. Based on the results of data analysis, the average validity score of the subject matter experts as a whole is 4.3 with very valid qualifications in accordance with the guidelines for the validity assessment criteria in Table 3.8. While the percentage of the results of the fun thinkers media reliability test conducted by subject matter experts obtained the results of 93\%. This shows that the media developed is reliable. Then the average validity score in terms of media experts as a whole is 4.4 with very valid qualifications in accordance with the guidelines for the validity assessment criteria in Table 3.8. While the percentage of the results of the fun thinkers media reliability test conducted by media experts obtained the results of $92 \%$. This shows that the media developed is reliable. Furthermore, the average validity score in terms of practitioner responses as a whole is obtained as 4.6 with very valid qualifications in accordance with the guidelines for the validity assessment criteria in Table 3.8. While the percentage of the results of the fun thinkers media reliability test conducted by the practitioners' responses, the results obtained are $96 \%$. This shows that the media developed is reliable. Then the average validity score in terms of student responses as a whole is obtained 4.8 with very valid qualifications in accordance with the guidelines for the validity assessment criteria in Table 3.8. While the percentage of the results of the media fun thinkers reliability test conducted by student responses, the results obtained are $97 \%$. This shows that the media developed is reliable. Thus the fun thinkers media based on fill-the-blank-question for elementary school students in grade 1 on the theme 3 my activities developed is valid and reliable, so that the fun thinkers media can be used in the learning process. 
Table 5. Feedback and Suggestions from Experts

\begin{tabular}{cccc}
\hline No. & \multicolumn{2}{c}{ Trial Subject } & \multicolumn{1}{c}{ Feedback and Suggestions } \\
\hline $1 . \quad \begin{array}{l}\text { Subject } \\
\text { Test }\end{array}$ & Content & Expert & $\begin{array}{l}\text { Given a number in each box about media fun thinkers. There are } \\
\text { several colors in the answer key to the question that is upside } \\
\text { down. There are some ambiguous questions (sentences have more } \\
\text { than one meaning). The missing words need to be changed into an } \\
\text { easier question form. }\end{array}$ \\
3. $\begin{array}{l}\text { Learning } \\
\text { Test }\end{array}$ & Media & $\begin{array}{l}\text { The color of the cover is made brighter, the font on the back cover } \\
\text { of media media fun thinkers should not use times new roman, the } \\
\text { font is adjusted to the contents inside, the instructions are too long } \\
\text { and are equipped with colored supporting images for each clue. }\end{array}$ \\
\hline
\end{tabular}

Based on the inputs provided by the experts, a product revision is carried out in order to improve the product developed to be on higher quality. The results of the revisions made are presented in Figure 3.

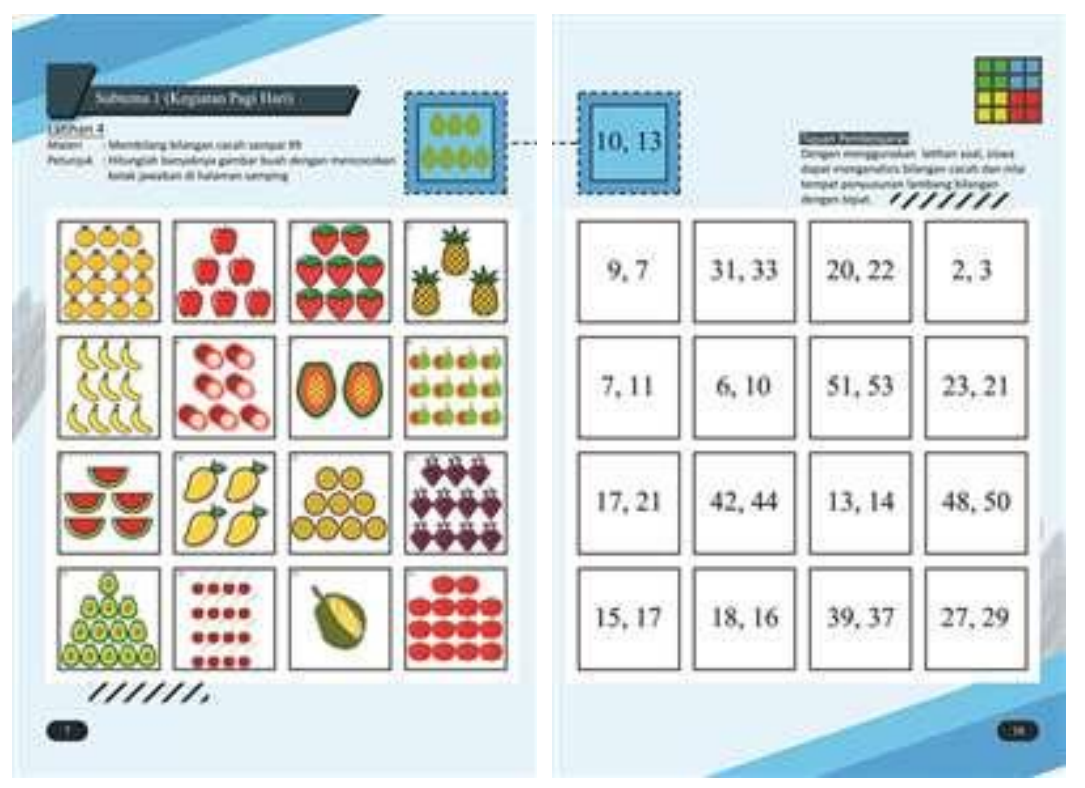

Figure 3. Results of the Revision of Media Fun Thinkers Based on the Fill the blank question

\section{Discussion}

Based on the results of data analysis that has been done, the fun thinkers media based on fill-theblank-question in theme 3 of my activities gets very good qualifications, so it is feasible to be applied in the learning process. Fun thinkers media based on fill-the-blank-question in theme 3 my activity has to be developed because it can facilitate students to learn independently and have fun so that students can understand the learning material well. In addition, the existence of this learning media can also help teachers in delivering learning materials to students, especially in grade I on theme 3 my activities. This is in accordance with the needs analysis showing that there is a need for learning media that can be used by teachers and students in learning activities during the COVID-19 pandemic. Funn thinkers media based on fill-the-blank-question in theme $3 \mathrm{my}$ activity gets very good qualifications and deserves to be applied considered by several factors, as follows.

First, fun thinkers media based on fill-the-blank-question in theme 3 my activities get very good qualifications and deserves to be applied because it can help in learning and able to attract students' interest in learning. In addition, in terms of the presentation aspect, the material presented is very interesting, thereby increasing students' attention and understanding the material. Also, it can indirectly improve students' critical thinking. Learning media can present learning materials in an innovative and creative way so as to increase students' motivation and interest in learning (Campen et al., 2020). In addition, from the aspect of accuracy, the clarity of the image has an impact on students. Learning media is purosed to link between information and students in order to stimulate students' thoughts, attention, and interests (Kucker, 2021; Maqfiroh et al., 2020). One of the factors that influence student learning outcomes is learning media. The benefits of using learning media are to clarify the material presentation 
and present abstract material to be more concrete so that the learning process is more effective (Polvieng, 2015; Rampai, 2013).

Second, fun thinkers media based on fill-the-blank-question gets very good qualifications and deserves to be applied because it eases students to understand the subject matter. In the design aspect, the clarity of the image, the suitability of the color selection, and the use of concrete examples are very good, so that students find it easier to understand and answer the questions given. In addition, the material presented in this learning media is in accordance with the competencies and learning objectives and is in accordance with the characteristics of the first grade students. In addition, the learning material is presented and explained through images so that it becomes easier to be understood (Gunawan et al., 2017; Muskania et al., 2019; Taqiya et al., 2019). The advantage of this fun thinkers media is can be used to improve students' thinking skills (Rezeki \& Atikah, 2020). Learning media can help students if they have difficulty understanding the material.

Third, fun thinkers media based on fill-the-blank-question gets very good qualifications and deserves to be applied because it can improve students' thinking skills. It increases student participation in learning caused by its efficiency and fun (Megawati, 2021; Rezeki \& Atikah, 2020). In the fun thinkers media based on fill-the-blank-question that is developed contains stages of flow, namely from the cover, user guide, Basic Competence (KD) indicators, table of contents, and exercises. Children are more focused on following the learning process that involves media, teachers and media components such as pictures (Rose et al., 2016). Based on this, the media is developed by combining several components to produce learning media that can attract interest in learning and add to the learning experience for students.

The findings of previous research regarding fun thinkers media also state that fun thinkers media can increase students' enthusiasm in learning (Bakhri, 2019; Megawati, 2021; Rezeki \& Atikah, 2020). Learning media in the form of fun thinkers media can help students and attract students' interest in learning so that the learning objectives can be accomplished. The advantages of this fun thinkers media are having an attractive appearance according to the characteristics of elementary school students, besides that this media provides practice questions that are presented in the form of games so as to stimulate students' thinking skills. However, this fun thinkers media based on fill-the-blank-question only develops on one learning theme. In addition, this media was only developed to a small group test with a limited number. It is hoped that further research can develop this research at the implementation stage through the experimental stage. The existence of fun thinkers media based on fill-the-blank-question can be used in the thematic learning process, especially on theme 3 of my activities. With this media, it can facilitate students to more easily understand the material during online learning.

\section{CONCLUSION}

Learning media in the form of fun thinkers media based on fill-the-blank-question on theme 3 my activities is appropriate to be applied in the learning process because in order to help students understand thematic subject matter, especially in theme 3 my activities. In addition, it can help the teacher in delivering the material. It is hoped that this media can facilitate students and improve student learning outcomes so that learning activities can be carried out effectively, efficiently and learning objectives can be achieved.

\section{REFERENCES}

Afifah, N. (2019). Efektivitas Media Ajar untuk Siswa Kelas Rendah Berbasis Nilai Karakter Toleransi terhadap Sesama dengan Berbantuan Aplikasi Sparkol Videoscribe. Modeling: Jurnal Program Studi PGMI, 6(2). https://doi.org/10.36835/modeling.v6i2.512.

Andriyani, N. L., \& Suniasih, N. W. (2021). Development of Learning Videos Based On Problem-Solving Characteristics of Animals and Their Habitats Contain in Science Subjects on 6th-Grade. Journal of Education Technology, 5(1), 37-47. https://doi.org/10.23887/jet.v5i1.32314.

Anugrahana, A. (2020). Hambatan, Solusi, dan Harapan: Pembelajaran Daring Selama Masa Pandemi Covid-19 oleh Guru Sekolah Dasar. Jurnal Pendidikan dan Kebudayaan, 10(3), 282-289. https://doi.org/10.24246/j.js.2020.v10.i3.p282-289.

Arianti, Wiarta, \& Darsana. (2019). Pengaruh Model Pembelajaran Problem Posing Berbantuan Media Semi Konkret terhadap Kompetensi Pengetahuan Matematika. Jurnal Ilmiah Sekolah Dasar, 3(4). https://doi.org/10.23887/jisd.v3i4.21765.

Asmuni. (2020). Problematika Pembelajaran Daring di Masa Pandemi Covid-19 dan Solusi Pemecahannya. Jurnal Paedagogy: Jurnal Penelitian dan Pengembangan Pendidikan, 7(4), 281-288. http://ojs.ikipmataram.ac.id/index.php/pedagogy/index. 
Bakhri, S. (2019). Animasi Interaktif Pembelajaran Huruf dan Angka Menggunakan Model ADDIE. INTENSIF: Jurnal Ilmiah Penelitian dan Penerapan Teknologi Sistem Informasi, 3(2), 130. https://doi.org/10.29407/intensif.v3i2.12666.

Campen, K., Carolien, A. N., Segers, E., \& Verhoeven, L. (2020). Effects of Audio Support on Multimedia Learning Processes and Outcomes in Students with Dyslexia. Computers and Education, 150(February), 103858. https://doi.org/10.1016/j.compedu.2020.103858.

Dewi, W. A. F. (2020). Dampak Covid-19 terhadap Implementasi Pembelajaran Daring di Sekolah Dasar. Jurnal Ilmu Pendidikan, 2(1), 55-61. https://edukatif.org/index.php/edukatif/index.

Ertem, Z., Araz, O. M., \& Cruz-Aponte, M. (2021). A Decision Analytic Approach for Social Distancing Policies during Early Stages of Covid-19 Pandemic. Decision Support Systems, 113630. https://doi.org/10.1016/j.dss.2021.113630.

Franchi, T. (2020). The Impact of the Covid-19 Pandemic on Current Anatomy Education and Future Careers: A Student's Perspective. Anatomical Sciences Education, 13(3), 312-315. https://doi.org/10.1002/ase.1966.

Gollwitzer, A., McLoughlin, K., \& Martel, C. (2021). Linking Self-Reported Social Distancing to Real-World Behavior during the Covid-19 Pandemic. Social Psychological and Personality Science. https://doi.org/10.1177/19485506211018132.

Gunawan, G., Sahidu, H., Harjono, A., \& Suranti, N. M. Y. (2017). The Effect of Project Based Learning with Virtual Media Assistance on Student's Creativity in Physics. Jurnal Cakrawala Pendidikan, 1(2). https://doi.org/10.21831/cp.v36i2.13514.

Hadiyati, N., \& Wijayanti, A. (2017). Keefektifan Metode Eksperimen Berbantu Media Benda Konkret terhadap Hasil Belajar IPA Siswa Kelas V Sekolah Dasar. JIPVA (Jurnal Pendidikan IPA Veteran), 1(1). https://doi.org/10.31331/jipva.v1i1.513.

Handayani, Hadi, Isbaniah, Burhan, \& Agustin. (2020). Corona Virus Disease 2019. Jurnal Respirologi Indonesia, 40(2). https://doi.org/10.36497/jri.v40i2.101.

Harahap, S. A., Dimyati, D., \& Purwanta, E. (2021). Problematika Pembelajaran Daring dan Luring Anak Usia Dini bagi Guru dan Orang Tua di Masa Pandemi Covid-19. Jurnal Obsesi : Jurnal Pendidikan Anak Usia Dini, 5(2), 1825-1836. https://doi.org/10.31004/obsesi.v5i2.1013.

Heo, M., \& Toomey, N. (2020). Learning with Multimedia: The Effects of Gender, Type of Multimedia Learning Resources, and Spatial Ability. Computers and Education, 146. https://doi.org/10.1016/j.compedu.2019.103747.

Herlina, H., \& Suherman, M. (2020). Potensi Pembelajaran Pendidikan Jasmani Olahraga dan Kesehatan (PJOK) di Tengah Pandemi Corona Virus Disease (Covid)-19 di Sekolah Dasar. Tadulako Journal Sport Sciences and Physical Education, 1-7. http://jurnal.untad.ac.id/jurnal/index.php/PJKR/article/view/16186.

Khamparia, A., \& Pandey, B. (2017). Impact of Interactive Multimedia in E-learning Technologies: Role of Multimedia in E-learning. Enhancing Academic Research with Knowledge Management Principles, April, 199-227. https://doi.org/10.4018/978-1-5225-2489-2.ch007.

Kristiawan, M., Aminudin, N., \& Rizki, F. (2021). Optimalisasi Pembelajaran Daring Berbasis Aplikasi Online bagi Calon Guru Pendidikan Anak Usia Dini. Jurnal Obsesi : Jurnal Pendidikan Anak Usia Dini, 5(2), 1905 - 1914. https://doi.org/10.31004/obsesi.v5i2.942.

Kucker, S. C. (2021). Processes and Pathways in Development Via Digital Media: Examples from Word Learning. Infant Behavior and Development, 101559. https://doi.org/10.1016/j.infbeh.2021.101559.

Lilawati, A. (2020). Peran Orang Tua dalam Mendukung Kegiatan Pembelajaran di Rumah pada Masa Pandemi. Jurnal Obsesi: Jurnal Pendidikan Anak Usia Dini, 5(1), 549. https://doi.org/10.31004/obsesi.v5i1.630.

Mansyur, A. R. (2020). Dampak Covid-19 terhadap Dinamika Pembelajaran di Indonesia. Education and Learning Journal, 1(2), 113. https://doi.org/10.33096/eljour.v1i2.55.

Maqfiroh, Khutobah, \& Budyawati. (2020). Pengembangan Media MOTIF (Monopoli Edukatif) dalam Pembelajaran Berbasis Multiple Intelligence. Cakrawala Dini: Jurnal Pendidikan Anak Usia Dini, 11(1), 64-74.

Mauludy, N. B. (2020). Dampak Covid-19 terhadap Penerapan "Belajar Daring” pada Siswa Luar Biasa di SD Bandar Kidul 2 Kota Kediri. Prosiding Seminar Nasional LP3M, 244-247. http://proceeding.semnaslp3m.unesa.ac.id/index.php/Artikel/article/download/123/139.

Megawati, N. K. S. M. S. (2021). Penerapan Metode Penugasan Berbantu Media Fun Thinkers Book untuk Meningkatkan Perkembangan Kognitif Anak Kelompok A. Prosiding Penelitian Pendidikan Dan Pengabdian 2021, 1(1), 164-171.

Muskania, R. T., Badariah, S., \& Mansur, M. (2019). Pembelajaran Tematik Menggunakan Media Video 
Scribe Pada Siswa Kelas IV Sekolah Dasar. Elementary: Islamic Teacher Journal, 7(1). https://doi.org/10.21043/elementary.v7i1.4927.

Nurkholis. (2020). Dampak Pandemi Novel-Corona Virus Disiase (Covid-19) terhadap Psikologi dan Pendidikan Serta Kebijakan Pemerintah. Jurnal PGSD, 6(1), 39-49.

Ota, M. K., Djou, A. M. G., \& Numbah, F. F. (2021). Problematika Pembelajaran Daring Siswa Kelas VII SMPN. Jurnal Pengabdian Masyarakat, 2(1), 74-81. https://doi.org/10.37478/mahajana.v2i1.769.

Pertiwi, I. N., Sumarno, \& Dwi, A. (2019). Pengaruh Model Make a Match Berbantu Media Kartu Bergambar terhadap Kemampuan Membaca dan Menulis. Mimbar PGSD Undiksha, 7(3), 261-270. https://doi.org/10.23887/jjpgsd.v7i3.19412.

Polvieng, T. (2015). The Development of Model Learning Media of Sorting Algorithm. Procedia - Social and Behavioral Sciences, 197, 1064-1068. https://doi.org/10.1016/j.sbspro.2015.07.333.

Putri, W. N. (2017). Pengaruh Media Pembelajaran terhadap Motivasi Belajar Bahasa Arab Siswa Madrasah Tsanawiyah. LISANIA: Journal of Arabic Education and Literature, 1(1), 1-16. https://doi.org/10.18326/lisania.v1i1.1160.

Putria, H., Maula, L. H., \& Uswatun, D. A. (2020). Analisis Proses Pembelajaran dalam Jaringan (Daring) Masa Pandemi Covid-19 pada Guru Sekolah Dasar. Jurnal Basicedu, 4(4), 861-870. https://doi.org/10.31004/basicedu.v4i4.460.

Rampai, N. (2013). The Development Model of Knowledge Management via Social Media to Enhance Graduated Student's Self-Directed Learning Skill. Procedia - Social and Behavioral Sciences, 103, 1006-1010. https://doi.org/10.1016/j.sbspro.2013.10.425.

Rezeki, \& Atikah, S. (2020). Pengembangan Media Pembelajaran Fun Thinkers Book Berbasis Scientific pada Tema 4 Berbagai Pekerjaan Subtema 1 Jenis-jenis Pekerjaan Kelas IV di SDN 060912 Medan Denai T. A 2020/2021. Jurnal Keluarga Sehat Sejahtera, 18(1), 36-45. https://doi.org/10.24114/jkss.v18i1.25069.

Rigianti, H. A. (2020). Kendala Pembelajaran Daring Guru Sekolah Dasar di Kabupaten Banjarnegara. Jurnal Elementary School, 7(2), 297-302. https://doi.org/10.31316/esjurnal.v7i2.768.

Rose, J. A., O'Meara, J. M., Gerhardt, T. C., \& Williams, M. (2016). Gamification: Using Elements of Video Games to Improve Engagement in an Undergraduate Physics Class. Physics Education, 51(5). https://doi.org/10.1088/0031-9120/51/5/055007.

Siahaan, M. (2020). Dampak Pandemi Covid-19 terhadap Dunia Pendidikan. Jurnal Kajian Ilmiah, 1(1), 7380. https://doi.org/10.31599/jki.v1i1.265.

Soucy, J. N., Owens, V. A. M., Hadjistavropoulos, H. D., Dirkse, D. A., \& Dear, B. F. (2016). Educating Patients about Internet-Delivered Cognitive Behaviour Therapy: Perceptions among Treatment Seekers and Non-Treatment Seekers Before and After Viewing an Educational Video. Internet Interventions, 6, 57-63. https: //doi.org/10.1016/j.invent.2016.09.003.

Susilo, A., Rumende, C. M., Pitoyo, C. W., Santoso, W. D., Yulianti, M., Herikurniawan, H., Sinto, R., Singh, G., Nainggolan, L., Nelwan, E. J., Chen, L. K., Widhani, A., Wijaya, E., Wicaksana, B., Maksum, M., Annisa, F., Jasirwan, C. O. M., \& Yunihastuti, E. (2020). Coronavirus Disease 2019: Tinjauan Literatur Terkini. Jurnal Penyakit Dalam Indonesia, 7(1), 45. https://doi.org/10.7454/jpdi.v7i1.415.

Syafari, Y., \& Montessori, M. (2020). Analisis Pembelajaran Daring terhadap Motivasi Belajar dan Prestasi Belajar Siswa di masa Pandemi Covid-19. Jurnal Basicedu, 5(3), 1295-1303. https://doi.org/10.31004/basicedu.v5i3.872.

Tafonao, T. (2018). Peranan Media Pembelajaran dalam Meningkatkan Minat Belajar Mahasiswa. Jurnal Komunikasi Pendidikan, 2(2), 1-13. https://doi.org/10.32585/jkp.v2i2.113

Talevi, D., Socci, V., Carai, M., Carnaghi, G., Faleri, S., Trebbi, E., Bernardo, A. D. I., Capelli, F., \& Pacitti, F. (2020). Mental Health Outcomes of the Covid-19 Pandemic Gli Esiti di Salute Mentale Della Pandemia di Covid-19. Riv Psichiatr, 55(3), 137-144. https://doi.org/10.1708/3382.33569.

Taqiya, Nuroso, \& Reffiane. (2019). Pengaruh Model Pembelajaran Terpadu Tipe Connected Berbantu Media Video Animasi. Mimbar PGSD Undiksha, 7(3), 289-295. https://doi.org/10.23887/jjpgsd.v7i3.19492.

Yuliani, E., \& Saputri, R. K. (2021). Perbandingan Penggunaan Platform Google Classrom dan Grup Whatsapp dalam Pembelajaran Online Selama Pandemi Covid-19. Jurnal Educatio FKIP UNMA, 7(1), 238-243. https://doi.org/10.31949/educatio.v7i1.934.

Zulfana, F., Purwadi, \& Mudzanatun. (2020). Pengaruh Model NHT Berbantu Media Ular Tangga terhadap Hasil Belajar Siswa Kelas IV di SD N 02 Ujung Pandan Jepara. Elementary School: Jurnal Pendidikan dan Pembelajaran Ke-SD-an, 7(1). https://doi.org/10.31316/esjurnal.v7i1.474. 